\title{
Accumulation and depuration of paralytic shellfish poisoning toxins by purple clam Hiatula rostrata Lighttoot
}

\author{
Chih Yu Chen ${ }^{\mathrm{a}, *}$, Hong Nong Chou ${ }^{\mathrm{b}}$ \\ ${ }^{a}$ Institute of Zoology, National Taiwan University, Taipei, Taiwan 10617, R.O.C. \\ ${ }^{\mathrm{b}}$ Institute of Fisheries Science, National Taiwan University, Taipei, Taiwan 10617, R.O.C.
}

Received 4 July 2000; accepted 31 October 2000

\begin{abstract}
Purple clams (Hiatula rostrata Lighttoot) accumulated paralytic shellfish poisoning (PSP) toxins produced by a toxic strain of the dinoflagellate Alexandrium minutum Halim for subsequent study of toxin distribution during depuration (detoxification by a nontoxic microalgal diet or starvation). The results confirm the data in the literature concerning the high toxicity of the digestive gland, and the depuration efficiency between feed with nontoxic microalgae and starvation is similar. The toxin profile of the purple clams was similar with that of Alexandrium minutum at the end of the exposure period; GTX4 and GTX1 were dominant. However, at the end of the depuration period, GTX3 and GTX2 were dominant. The non-visceral tissues were toxic after feeding with toxic algae. The toxicity was low and the profile were also similar with that of the toxic algae. No PSP toxins other than GTX-1, 2, 3 and 4 were detected in the experimental period. (C) 2001 Elsevier Science Ltd. All rights reserved.
\end{abstract}

Keywords: Purple clams; Paralytic shellfish poisoning toxins; Dinoflagellates; Alexandrium minutum

\section{Introduction}

The toxic dinoflagellate Alexandrium minutum Halim is a recurrent cause of toxicity associated with paralytic shellfish poisoning (PSP) toxins in southern Taiwan (Hwang et al., 1999). The purple clam Hiatula rostrata Lighttoot is known for prolonged PSP toxin retention, and the accumulation of high toxin levels (Hwang et al., 1987). Two food poisoning incidents due to ingesting the purple clam occurred in Tungkang, Pingtung Prefecture in 1986 and in Tungshih, Chia-yi Prefecture in 1991 (Hwang et al., 1995).

Filter-feeding bivalve molluscs vary widely in their capacity to ingest toxigenic dinoflagellates and to sequester PSP toxins in various anatomical compartments (Lassus et al., 1989; Bricelj et al., 1991). An understanding of toxin conversions in shellfish is critically important since toxins of low potency in dinoflagellate cells can be converted to highly potent toxins through bacterial, enzymatic, or $\mathrm{pH}-$ mediated activity (Shimizu and Yoshioka, 1981; Sullivan et al., 1983), thereby affecting net toxicity. In previous

\footnotetext{
* Corresponding author. Tel.: +886-2-273-77850; fax: +886-2273-77669.

E-mail address: cychen@mail.stic.gov.tw (C.-Y. Chen).
}

studies (Chen and Chou, 1998), we found that another species of purple clams, Hiatula diphos, could accumulate PSP toxins to a high concentration ( $3149 \mu \mathrm{g}$ STX eq/100 g shellfish meat) in a short time (by 6 days). The main purpose of this study was to determine: (1) the toxic algal ingestion rate and toxin assimilation efficiency; (2) the rate of toxicity and toxin incorporation and loss in this species, comparing the depuration rate between clams fed with non-toxic algae and clams which were starved; and (3) the localization and fate of individual toxins in different purple clam tissues following exposure to toxic algae.

\section{Materials and methods}

\subsection{Materials and culture environment}

Strain AMTK-1 of Alexandrium minutum Halim was isolated in 1986 from the Tungkang area where PSP occurred due to the ingestion of purple clams. The unialgal isolates were batch cultured in K-medium (Keller and Guillard, 1985) and illuminated with continuous light of $60 \mu \mathrm{mol} \mathrm{m}^{-2} \mathrm{sec}^{-1}$ at $20-22^{\circ} \mathrm{C}$. Pavlova salina cultures, used as nontoxic live feed for control purposes, were also 


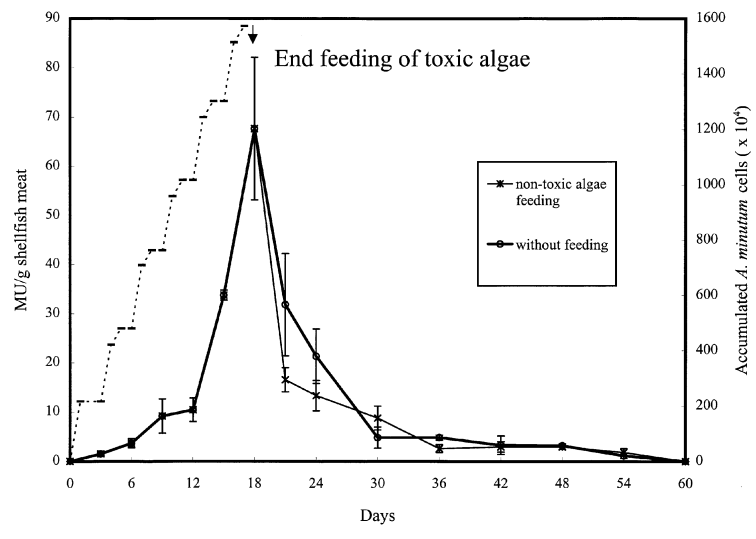

Fig. 1. The amount of ingested toxic dinoflagellate (A. minutum) cells (dashed line) and the mouse unit toxicity detected in purple clams $(H$. rostrata) during the accumulation and depuration period (solid line). Algal cells taken by each of the purple clams were calculated from the daily reduction of the cells. Values of toxicity are means \pm SE converted from HPLC analysis of four replications.

maintained under the same conditions. Algal cells of both toxic and nontoxic species were harvested for feeding experiments in exponential growth phase.

Purple clams (Hiatula rostrata Lighttoot) average $6.86 \mathrm{~cm}(S E=0.57, n=200)$ in shell length (mean tissue wet weight $=9.08 \mathrm{~g}, S E=1.28$ ), were collected from an aquaculture pond in Tungkang, Pingtung Prefecture. The clams were brought to the laboratory and placed in a 1301 tank with filtered sea water ( $20 \mathrm{ppt}$ salinity). Continuous aeration was carried out at $17 \pm 2^{\circ} \mathrm{C}$ throughout the holding period. An acclimation period of 1 week preceded the experiment in order to eliminate individuals that were too weak or showed physiological defects. During the exposure period, lasting 18 days, the clams were fed with $A$. minutum at 2-day intervals and exposed each time to $6.05 \pm 0.33 \times 10^{8}$ cells. During the depuration period, starting at day 19 and lasting 42 days, clams were divided into two groups: (1) in one group, clams were fed with Pavlova salina at 3-day intervals and exposed to $1.18 \pm 0.85 \times 10^{8}$ cells; (2) in the other group, clams were starved.

\subsection{Assay of toxicity and HPLC}

The toxicity of purple clams were monitored during the contamination and depuration periods. The clams $(n=4)$ were periodically removed for toxin analysis after dissection into three parts: digestive gland, siphon and other tissues (including the foot, gill, adductor muscle and mantle). The method of extraction of PSP toxins was according to Chen and Chou (1998). Tissues were homogenized with $15 \mathrm{ml}$ $0.1 \mathrm{M} \mathrm{HCl}$, the extracts were defatted twice with chloroform, and the aqueous layer was ultrafiltered by centrifugation (10,000 MW cut-off). Subsequently, $10 \mu \mathrm{l}$ of the supernatant were injected into the HPLC with a post-column reaction system (modified from Nagashima et al., 1987). The column used was a $5 \mu \mathrm{m}, 250 \times 4.6 \mathrm{~mm}$ Cosmosil $5 \mathrm{C} 18-\mathrm{AR}$ column at a flow rate of $0.8 \mathrm{ml} / \mathrm{min}$. Fluorescent PSP toxin derivatives were detected using a Hitachi F-1000 spectrophotometer with excitation at $336 \mathrm{~nm}$ and emission at $390 \mathrm{~nm}$.

\subsection{Calculation}

The conversion of peak areas of HPLC-resolved toxins into mouse units was according to the following formulation: Toxicity $(\mathrm{MU} / \mathrm{ml})=\left(19.7 A_{1}+0.57 A_{2}+1.61\right.$ $\left.A_{3}+8.11 A_{4}\right) \times 10^{-6}$, where $\mathrm{MU}=1$ mouse unit and $A_{1}, A_{2}$, $A_{3}, A_{4}$ represented the peak areas of the resolved toxins, GTX-1, 2, 3, and 4 respectively. The suitability of the formula was based on the fact that there were no resolved peaks other than those corresponding to the above four toxins in the tested material. The calibration factors for each toxin were adopted from mouse assays of partially purified toxin mixtures with the reported specific toxicity (Genenah and Shimizu, 1981) and the reported specific fluorescent response (Sullivan et al., 1985). This provides a way to convert the HPLC data to the generally accepted mouse toxicity units as STX equivalents (AOAC, 1995). In our case it was observed that $1 \mathrm{MU}$ (ICR strain, male, $20 \mathrm{~g}$ ) was equivalent to $0.259 \mu \mathrm{g} / \mathrm{ml}$ STX by the calibration procedure suggested by the AOAC ( $\mathrm{Su}$ and $\mathrm{Chou}, 1993$ ). According to the above formula and the corresponding mouse responses to each toxin, the specific amount $(\mu \mathrm{mol})$ of each individual toxin could thus be calculated from its peak area. Correlation factors for each toxin were $1.2 \times 10^{-10}, 7.2 \times 10^{-12}, 7.2 \times 10^{-12}$, and $1.2 \times 10^{-10}$ for GTX-1, 2, 3, and 4, respectively. The toxicity and amount of partially purified toxin mixtures were certified by Dr Y. Oshima, Tohoku University, Japan (personal communication).

\section{Results}

Average toxicities accumulated in each clam were indicated by the total mouse units that were converted from HPLC analysis of the shellfish extracts and the accumulated cells of toxic dinoflagellates taken by their filter-feeding activities (Fig. 1). In A. minutum, the relative amount of individual toxins was constant throughout the feeding period. In this experiment, the toxicity of $A$. minutum ranged from $7.0 \times 10^{-5} \mathrm{MU} /$ cell to $1.0 \times 10^{-4} \mathrm{MU} /$ cell. In the purple clams, the maximal PSP levels were reached on the last day of exposure (1753 $\mu \mathrm{g}$ STX eq/100 g shellfish meat), which was half of the toxicity of ingested dinoflagellates. The clams lost $75 \%$ of their body burden of toxin on the first day of feeding with nontoxic algae and $50 \%$ on the first day of starvation (Fig. 1). That is, the group fed non-toxic algae showed more rapid initial gut clearance.

The changes in toxicity levels over an 18-day period 


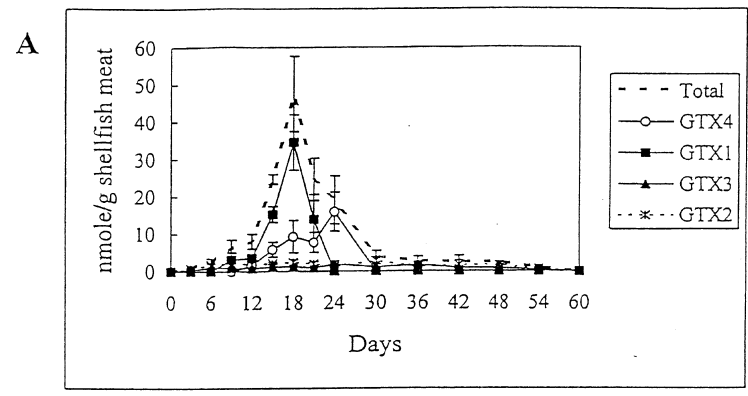

B

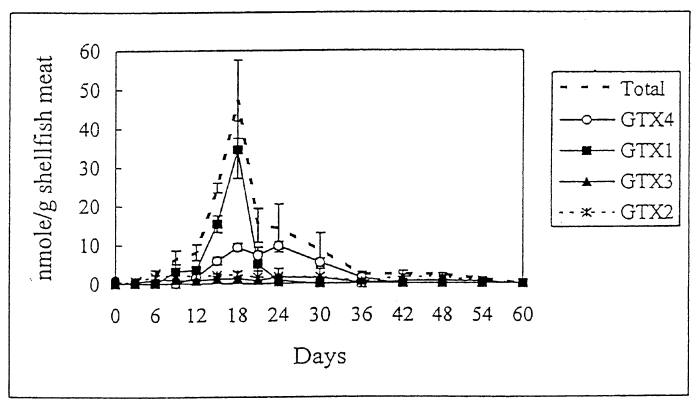

Fig. 2. Changes of PSP toxin compositions in purple clams (H. rostrata), during the feeding of dinoflagellate (A. minutum) and following: (a) feeding of nontoxic algae and (b) starvation. Values of toxicity are means \pm SE converted from HPLC analysis of four replications.

showed a rapid loss of toxicity during the first 6 days and then a relatively constant concentration during the next 24 days (both those starved and those fed with non-toxic algae) (Fig. 1). From this point of view, the best detoxification method is to delay the time of sale, so that toxins can be released from the shellfish. The digestive gland accounts for most of the toxicity in purple clam, which exhibits faster toxin decay rates, and detoxification generally proceeds in two stages (Fig. 2): (1) rapid loss of toxin (primarily in the faeces) because of clearance of unassimilated toxin from undigested cells or in dissolved form in the gut lumen, and (2) slower release of assimilated toxin either bound to the digestive gland or incorporated within other tissues.

Detoxification rates of the purple clams are described by the general exponential equation $T_{\mathrm{t}}=T_{0} e^{-\mathrm{kt}}$, which becomes: $\ln T_{\mathrm{t}}=3.2342-0.0903 \mathrm{t} ; r^{2}=0.89$ (for the fed nontoxic algae group) and $\ln T_{\mathrm{t}}=3.3485-0.0957 \mathrm{t}$; $r^{2}=0.87$ (for the starved group) where $t=$ detoxification period (day); $T_{0}=$ maximum total toxin amount $(\mathrm{nmol} / \mathrm{g}$ shellfish meat); $T_{\mathrm{t}}=$ total toxin amount (nmol/g shellfish meat) in detoxification period; and the slopes represent the toxin decay coefficient $k$. The toxin half-life for the fed nontoxic algae group was 7.7 days and 7.2 days for the starved group.

During the initial days of feeding, GTX3 and GTX2 were the major toxins in the shellfish, and the toxin profile was different from that of the dinoflagellates. In A. minutum,
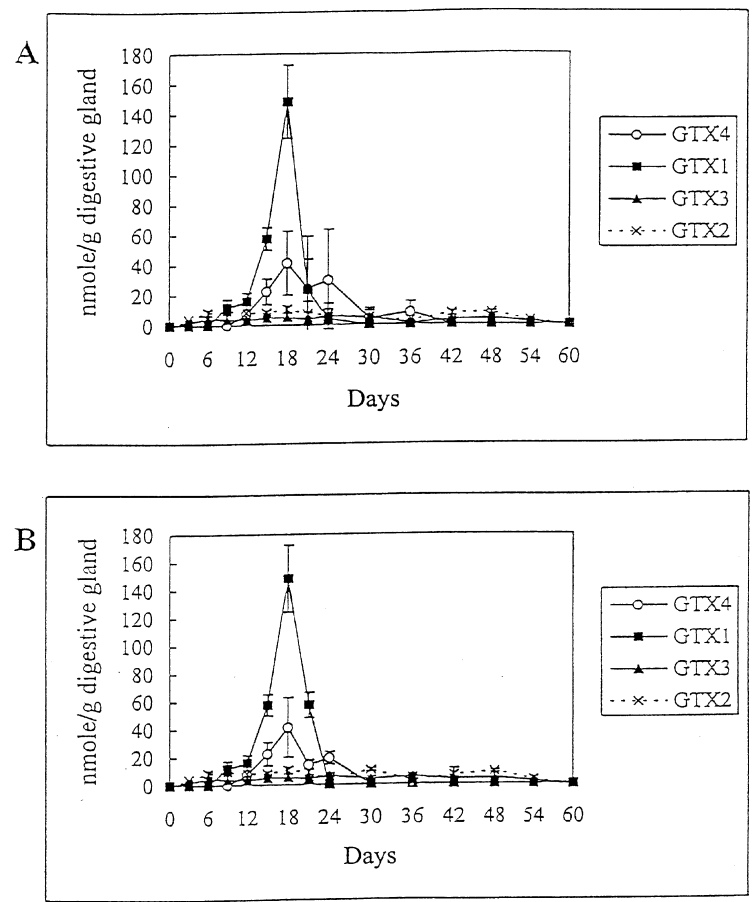

Fig. 3. Changes of PSP toxin compositions in digestive glands of the purple clams $(H$. rostrata), during the feeding of dinoflagellate (A. minutum) and following: (a) feeding of nontoxic algae and (b) starvation. Values of toxicity are means \pm SE converted from HPLC analysis of four replications.

GTX4 and GTX1 were the dominant toxins $(92-94 \%)$ and biotransformation might have occurred from GTX4 and GTX1 to GTX3 and GTX2. At the end of the contamination period, we found undigested algal cells by microscopy of the digestive glands of purple clams, so the toxin profile was similar to that of the toxic algae. GTX4 and GTX1 accounted for $92.2 \%$ of the molar toxin content in the shellfish. During the depuration period, GTX3 and GTX2 were the major PSP toxins, so that the results resembled those of the field survey of our study (data not shown). By day 24, the amount of GTX4 had increased, whereas GTX1 had decreased. If this was by epimerization, thermodynamics would favor the opposite pattern, which indicated that enzymatic transformation might have occurred. By day 54, GTX3 and GTX2 were the only toxins that could be detected. By day 60 , toxins levels were undetectable both in the clams fed with non-toxic algae and in starved clams. The concentrations of GTX3 and GTX2 remained fairly constant during the experiment, which means that the decay rate among the toxins was different, and that biotransformation might have occurred. We suggest that the purple clams tended to selectively retain GTX3 and GTX2 during the depuration period, or that GTX4 and GTX1 have a shorter half life than GTX3 and GTX2 (Fig. 3).

In non-visceral tissues, an interesting result was that the 

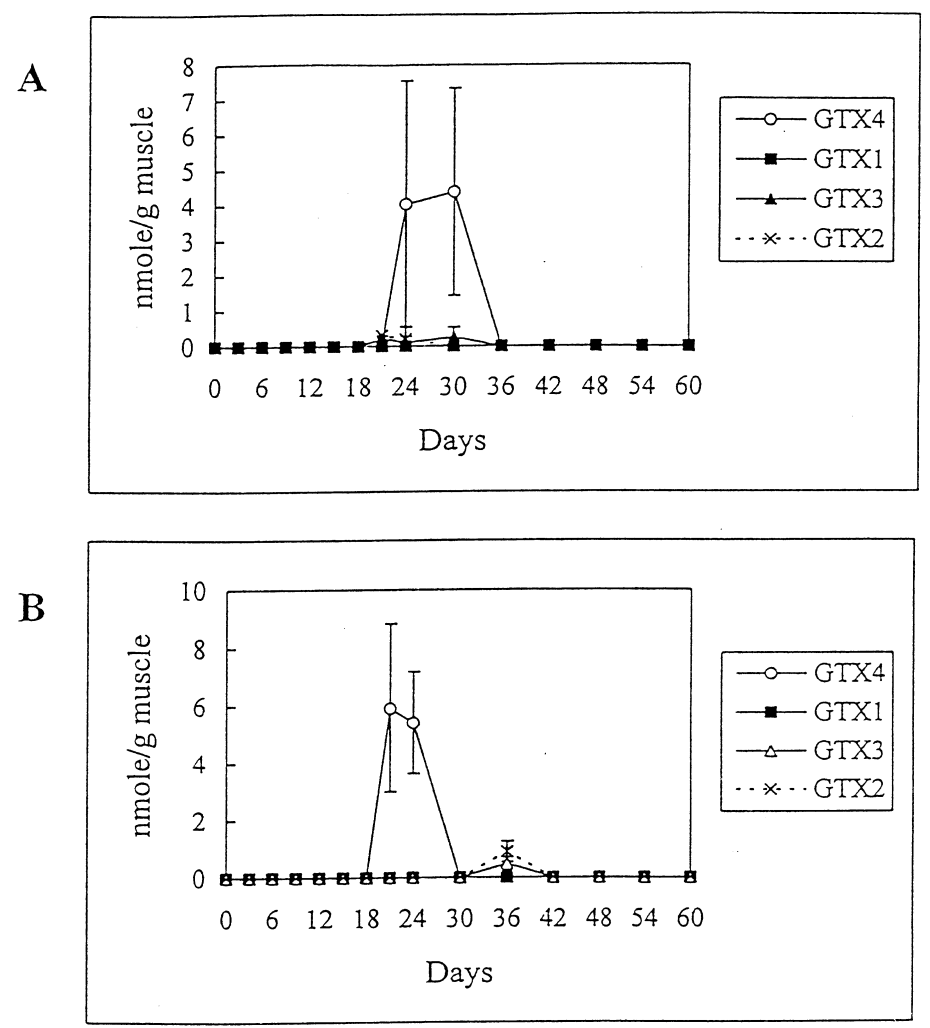

Fig. 4. Changes of PSP toxin compositions in other tissues of the purple clams (H. rostrata), during the feeding of dinoflagellate (A. minutum) and following: (a) feeding of nontoxic algae and (b) starvation. Values of toxicity are means \pm SE converted from HPLC analysis of four replications.

toxicity could only be detected during the depuration period. After feeding with toxic algae, other tissues became toxic at day 21 and toxicity disappeared at day 36 in the group fed nontoxic algae. In the starvation group, other tissues became toxic by day 21 and toxicity disappeared at day 42 . Whether the purple clams are a special case needs further experiments to determine. In other tissues, the major toxin was GTX4, and the amounts of the other three toxins were low (both in starved clams and in those fed with non-toxic algae) (Fig. 4). In the siphon, GTX4 was the only toxin which appeared during the depuration period (Fig. 5).

\section{Discussion}

In Taiwan, the purple clam Hiatula rostratais the only shellfish species which was reported to result in food poisoning incidents (Hwang et al., 1995). Compared with other economically important bivalves, namely oysters Crassostrea gigas and hard clams Meretrix lusoria, purple clams accumulated higher toxicity than these two bivalves in previous feeding experiments (Chou and Su, 1989). Recent results have shown, however, that toxin production of the algae may not be constant, but varies with the growth condi- tions of the algae (Boyer et al., 1987). The variability in toxin production implies that it is impossible to calculate the toxicity in the clams from the ingestion rate, because toxins might have been released into the water from old or dead A. minutum cells, and various clam species may differ significantly in detoxification rates. We also found that the depuration efficiency of purple clams was high, so that they could not accumulate PSP toxins over a long time. In this experiment, the depuration efficiency of purple clam was similar between starved individuals and those fed with nontoxic microalgae, which means that the effect on toxin metabolism of the two depuration methods was similar. Biphasic (fast and slow) depuration kinetics were also found for PSP toxicity in the scallop Pecten maximus (Lassus et al., 1989). Lee (1993) suggested a two-compartment model based upon the uptake and detoxification kinetics of PSP toxins which might be sufficient to describe toxin dynamics of whole shellfish. Detoxification of the other tissues can occur either by transfer of toxins back to the digestive gland from where they are ultimately excreted, or perhaps by direct loss through leakage or diffusive excretion from the surface of these organs. In our experiments, the processes involved in toxin kinetics appear to involve only first-order processes, so one-compartment modelling can be 


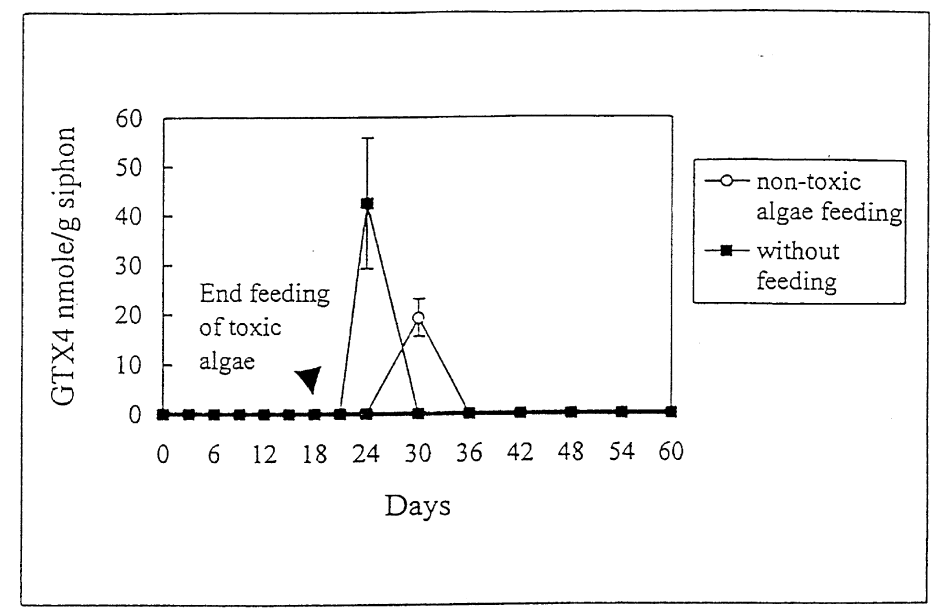

Fig. 5. PSP toxin compositions in siphons of purple clams (H. rostrata), during the feeding of dinoflagellate (A. minutum) and the following feeding of nontoxic algae or starvation. Values of toxicity are means \pm SE converted from HPLC analysis of four replications.

used, which was similar with the results of blue mussels, Mytilus edulis (Silvert and Cembella, 1995). We found that purple clams are able to detoxify to acceptable levels for human consumption within ca. 3-4 weeks, similar to the northern quahog Mercenaria mercenaria (Bricelj et al., 1991).

Comparing the toxicity of non-visceral tissues of the purple clam with other bivalves (Bricelj et al., 1990, 1991, 1995; Lassus et al., 1996), the appearance of toxicity in nonvisceral tissues only in the depuration period is unique. Whereas other clams showed an increasing trend in toxicity in the organs other than digestive gland in contamination period. Whether the feeding time or other factors are relevant to anatomical distribution of PSP toxicity still needs to be confirmed. In purple clams, the siphons did not accumulate significant toxin levels, but in the Alaskan butter clam, Saxidomus giganteus, PSP toxins were concentrated in pigmented, melanin-containing tissues such as the siphons (Smolowitz and Doucette, 1995). As in the siphons, the toxin concentrations in other non-visceral tissues of purple clams were also low, similar to those found in other clams (Bricelj et al., 1990). However, during the depuration period, GTX3 and GTX2 were the major toxins in the digestive gland whereas GTX4 was the major and only PSP toxin detected in non-visceral tissues. The different toxin composition in different portions might be due to differential toxin retention ability among different organs.

It is noteworthy that STX and other PSP toxins were not detected during the contamination and depuration periods. A previous study of toxin profiles showed that naturally contaminated purple clams contained trace amounts of neoSTX and STX (Hwang et al., 1987). In contrast, purple clams did not contain STX during this experiment and STX was not detected in the A. minutum strain used in the toxin uptake study. The appearance of STXs in a previous field survey report (Hwang et al., 1987) may have originated from toxin biotransformation in tissues, through artifactual conversion during sample preparation, or through dinoflagellates other than A. minutum which contain STX in the field.

\section{Acknowledgements}

This work was supported by grants from the National Science Council (Grant No.: NSC86-2113-M002-014), and the Council of Agriculture (Grant No.: COA86-A-6.3F-11(2), Taiwan, Republic of China.

\section{References}

AOAC (Association of Official Analytical Chemist), 1995. Paralytic shellfish poisons biological method final action. In: Horwitz, W. (Ed.). Official Methods of the Association of Official Analytical Chemists, 15th ed, Vol. 35. AOAC, Washington, DC, pp. 2122.

Boyer, G.L., Sullivan, J.J., Anderson, R.J., Harrison, P.J., Taylor, F.J.R., 1987. Effects of nutrient limitation on toxin production and composition in the marine dinoflagellate Protogonyaulax tamarensis. Mar. Biol. 96, 123-128.

Bricelj, V.M., Cembella, A.D., 1995. Fate of gonyautoxins in surfclams, Spisula solidissima, grazing upon toxigenic Alexandrium. In: Lassus, P., Arzul, G., Erard, E., Gentien, P., Marcaillou, C. (Eds.). Harmful Marine Algal Blooms. Lavoisier, Paris, pp. 413-418.

Bricelj, V.M., Lee, J.H., Cembella, A.D., 1991. Influence of dinoflagellate cell toxicity on uptake and loss of paralytic shellfish toxins in the northern quahog, Mercenaria mercenaria. Mar. Ecol. Prog. Ser. 74, 33-46.

Bricelj, V.M., Lee, J.H., Cembella, A.D., Anderson, A.D., 1990. Uptake kinetics of paralytic shellfish toxins from the dinoflagellate Alexandrium fundyense in the mussel Mytilus edulis. Mar. Ecol. Prog. Ser. 63, 177-188. 
Chen, C.Y., Chou, H.N., 1998. Transmission of the paralytic shellfish poisoning toxins, from dinoflagellate to gastropod. Toxicon $36,515-522$.

Chou, H.N., Su, H.M., 1989. Allelochemicals in marine ecosystems. In: Chou, C.H., Waller, G.R. (Eds.). Phytochemical Ecology: Allelochemicals, Mycotoxins and Insect Pheromones. Academia Sinica Monograph Series No. 9, Institute of Botany, Taipei, pp. 119-128.

Genenah, A.A., Shimizu, Y., 1981. Specific toxicity of paralytic shellfish poisons. J. Agri. Food Chem. 29, 1289-1291.

Hwang, D.F., Noguchi, T., Nagashima, Y., Liao, I.C., Hashimoto, K., 1987. Occurrence of paralytic shellfish poison in the purple clam Soletellina diphos (Bivalve). Nippon Suisan Gakkaishi 53, 623-626.

Hwang, D.F., Tsai, Y.H., Cheng, C.A., Liao, I.C., Jeng, S.S., Noguchi, T., Hashimoto, K., 1995. Two food poisoning incidents due to ingesting the purple clam occurred in Taiwan. J. Natural Toxins 4, 173-179.

Hwang, D.F., Tsai, Y.H., Liao, H.J., Matsuoka, K., Noguchi, T., Jeng, S.S., 1999. Toxins of the dinoflagellate Alexandrium minutum Halim from the coastal waters and aquaculture ponds in southern Taiwan. Fish. Sci. 65, 171-172.

Keller, M.D., Guillard, R.R.L., 1985. Factors significant to marine dinoflagellate culture. In: Anderson, D.M., White, A.W., Baden, D.G. (Eds.). Toxic Dinoflagellates. Elsevier, New York, pp. 113-116.

Lassus, P., Fremy, J.M., Ledoux, M., Bardouil, M., Bohec, M., 1989. Patterns of experimental contamination by Protogonyaulax tamarensis in some French commercial shellfish. Toxicon 27, 1313-1321.
Lassus, P., Bardouil, M., Ledoux, M., Bohec, M., Murail, I., Fremy, J.M., 1996. Role of the kidneys in bioaccumulation of paralytic toxins by scallop (Pecten maximus) tissues. J. Natural Toxins 5 , 107-115.

Lee, J., 1993. The kinetics of PSP toxin transfer from the toxic dinoflagellate, Alexandrium spp. to two bivalve mollusc species, Mytilus edulis and Mercenaria mercenaria. MS Thesis, State University of New York, Stony Brook, New York.

Nagashima, Y., Maruyama, J., Noguchi, T., Hashimoto, K., 1987. Analysis of paralytic shellfish poison and tetrodotoxin by ionpairing high performance liquid chromatography. Nippon Suisan Gakkaishi 53, 819-823.

Shimizu, S.E., Yoshioka, M., 1981. Transformation of paralytic shellfish toxins as demonstrated in scallop homogenates. Science 212, 547-549.

Silvert, W.L., Cembella, A.D., 1995. Dynamic modelling of phycotoxin kinetics in the blue mussel, Mytilus edulis, with implications for other marine invertebrates. Can. J. Fish. Aquat. Sci. 52, 521-531.

Smolowitz, R., Doucette, G., 1995. Immunohistochemical localization of saxitoxin in the siphon epithelium of the butter clam, Saxidomus giganteus. Biol. Bull. 189, 229-230.

Su, H.M., Chou, H.N., 1993. Harmful microalgae and detection methods for shellfish poisoning. COA Fish. Ser. 43, 36-43.

Sullivan, J.J., Wekell, M.M., Kentala, L.L., 1985. Application of HPLC for the determination of PSP toxins in shellfish. J. Food Sci. 50, 26-29.

Sullivan, J.J., Iwaoka, W.T., Liston, J., 1983. Enzymatic transformation of PSP toxins in the littleneck clam (Protothaca staminea). Biochem. Biophys. Res. Comm. 114, 465-472. 